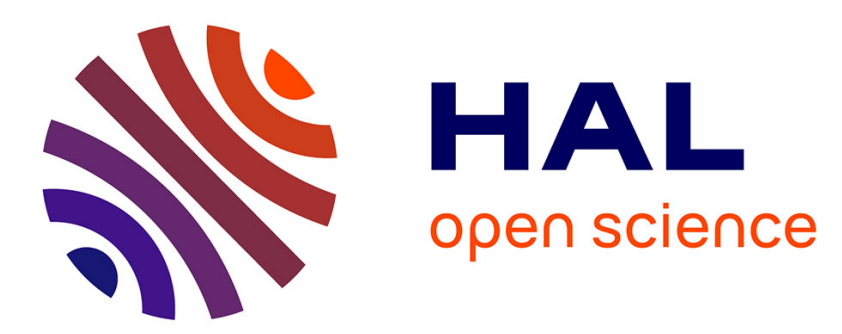

\title{
An inter-ocean comparison of coral endemism on seamounts: the case of Chrysogorgia
}

Eric Pante, Scott France, Delphine Gey, Corinne Cruaud, Sarah Samadi

\section{To cite this version:}

Eric Pante, Scott France, Delphine Gey, Corinne Cruaud, Sarah Samadi. An inter-ocean comparison of coral endemism on seamounts: the case of Chrysogorgia. Journal of Biogeography, 2015, 42 (10), pp.1907-1918. 10.1111/jbi.12564 . hal-01242420

\section{HAL Id: hal-01242420 \\ https://hal.science/hal-01242420}

Submitted on 12 Dec 2015

HAL is a multi-disciplinary open access archive for the deposit and dissemination of scientific research documents, whether they are published or not. The documents may come from teaching and research institutions in France or abroad, or from public or private research centers.
L'archive ouverte pluridisciplinaire HAL, est destinée au dépôt et à la diffusion de documents scientifiques de niveau recherche, publiés ou non, émanant des établissements d'enseignement et de recherche français ou étrangers, des laboratoires publics ou privés. 
1 Original Article

2

3 LRH: E. Pante et al.

4 RRH: Coral endemism on seamounts

5

6 An inter-ocean comparison of coral endemism on seamounts: the case of Chrysogorgia 7

8 Eric Pante ${ }^{1,2^{*}}$, Scott C. France ${ }^{1}$, Delphine Gey $^{3}$, Corinne Cruaud ${ }^{4}$ and Sarah Samadi ${ }^{3}$ 9

101 Department of Biology, University of Louisiana at Lafayette, Lafayette, LA, USA

11 2Littoral, Environnement et Sociétés, UMR 7266 CNRS, Université de La Rochelle, La Rochelle,

12 France, ${ }^{3} I S Y E B$ - UMR 7205 - CNRS, MNHN, UPMC (University Paris 06), EPHE - Muséum

13 national d'Histoire naturelle, Sorbonne Universités, CP26, F-75231 Paris cedex 05, France,

$14{ }^{4}$ GENOSCOPE, Centre National de Séquençage, Evry, France

15

16 *Correspondence: Eric Pante, Littoral, Environnement et Sociétés, UMR 7266 CNRS,

17 Université de La Rochelle, 17000 La Rochelle, France.

18 E-mail: pante.eric@gmail.com

19

20 
ABSTRACT

21 Aim The biogeography of seamount fauna remains poorly known, with less than $1 \%$ of the

22 world's seamounts having been investigated. Here, we report data on the geographical

23 isolation of species in the octocoral genus Chrysogorgia from south-west Pacific seamounts

24 and slopes, and contrast the results with patterns observed in the north-western Atlantic.

25 Location Seamounts of the Norfolk Ridge (NR) and Loyalty Ridge (LR), the slope of New

26 Caledonia, and the Matthew and Hunter Islands, south-west Pacific Ocean, with

27 comparative material from the Pacific and Atlantic oceans.

28 Methods The mitochondrial gene mtMutS was used to measure diversity within

29 Chrysogorgia. Community structure was analysed using rarefaction, multivariate analyses,

30 parsimony analysis of endemicity and analysis of molecular variance. The impact of

31 underestimating species richness when using mitochondrial haplotypes was tested using

32 simulations.

33 Results 634 colonies and 31 haplotypes were sampled from New Caledonia. Contrary to

34 what was observed in the north-western Atlantic, seamount-scale endemism of south-west

35 Pacific Chrysogorgia was substantial (9\% and 32\% for haplotypes with $n \geq 20$ and $n \geq 2$,

36 respectively). LR sheltered $64 \%$ of the New Caledonian haplotype diversity. Assemblages

37 were structured less by habitat type (slope versus seamounts) than by depth. Rarefaction

38 analyses suggested that LR and NR seamounts hold more species than the New Caledonian

39 slope, but additional sampling in the south-western Pacific (133 colonies) revealed that

40 some seemingly geographically restricted haplotypes from New Caledonia have wide

41 geographical distributions, reaching as far as Taiwan.

42 Main conclusions The distribution of Pacific Chrysogorgia is characterized by high levels of

43 rarity, patchiness and diversity, with the levels of seamount-scale and seamount-chain-

44 scale endemism higher than in the Atlantic. We hypothesize that the contrast between the

45 wide geographical distribution of Atlantic Chrysogorgia haplotypes and the higher

46 proportion of endemics in the Pacific is largely explained by differences in depth between

47 the seamounts of these two regions. 
Keywords

50 Atlantic Ocean, marine biogeography, marine connectivity, Octocorallia, Pacific

51 Ocean, parsimony analysis of endemicity, species delimitation, seamount.

\section{INTRODUCTION}

54 Seamounts, typically defined as undersea mountains that rise above the sea floor, are 55 among the most ubiquitous underwater features in the oceans (Wessel et al., 2010), and

56 constitute one of the largest marine biomes, with a total surface area similar to that of

57 Europe and Russia combined (Etnoyer et al., 2010; Yesson et al., 2011). The geological and

58 hydrographical setting in which seamounts are found makes them a noteworthy system for 59 the study of deep-sea biogeography. Most seamounts are volcanic in origin, and they are 60 commonly characterized by hard substrates and relatively steep slopes, features that are 61 rare in the deep sea (Rogers, 1994). They emerge at island arcs, mid-ocean ridges and in 62 intraplate hotspot settings, forming chains (Wessel, 2007). Because of these geological 63 attributes, seamounts may act as stepping stones between patches of suitable habitats on 64 continental shelves and oceanic ridges, and contribute to pan-oceanic dispersal (Ekman, 65 1953; Hubbs, 1959). On the other hand, hydrographical features such as Taylor caps, local 66 upwelling, jets and eddies (reviewed in Rogers, 1994), and sheer geographical isolation, 67 may significantly impede dispersal between habitat patches (Parker \& Tunnicliffe, 1994).

One question that has generated great interest and debate among deep-sea

69 biologists is whether the fauna associated with seamounts is highly endemic. The

70 topographical and hydrographical conditions associated with seamounts could contribute 71 to faunal isolation and the accumulation of highly endemic taxa (Hubbs, 1959). Wilson \&

72 Kaufmann (1987) provided the first global assessment of levels of endemism on

73 seamounts, and reported that $11.6 \%$ of fishes and $15.4 \%$ of invertebrates were endemic to

74 individual seamounts or seamount groups. Since this seminal review, many estimates of 75 endemism have been published, ranging from 0 to 100\%, reflecting various geographical

76 ranges and sampling efforts (Stocks \& Hart, 2007). Most notably, Parin et al. (1997)

77 compiled information from 22 seamounts of the Nazca and Sala y Gómez chains in the

78 south-eastern Pacific, and found that $44-51 \%$ of fishes and invertebrates were seamount 
endemics. Richer de Forges et al. (2000), summarizing the results of 24 exploration cruises,

80 found that $29-34 \%$ of 850 fish and invertebrate species collected from the Norfolk Ridge,

81 Lord Howe and Tasmanian seamounts were potential endemics.

$82 \quad$ From these studies emerged the general paradigm that seamounts harbour high

83 levels of endemism (Rowden et al., 2010a). Even though this paradigm is largely

84 unsupported by recent studies (Samadi et al., 2006; Stocks \& Hart, 2007; Hall-Spencer et

85 al., 2007; 0'Hara, 2007; Lundsten et al., 2009a,b; McClain et al., 2009; Howell et al., 2010),

86 the debate is not closed. Indeed, a minuscule proportion of seamounts have been

87 biologically sampled (less than 1\%; Staudigel et al., 2010), and the scarcity of data prevents

88 us from conceptualizing the processes that shape and maintain seamount faunal assemblages (see, for example, reviews by McClain, 2007; Clark et al., 2012). In addition,

90 most current estimates of endemism are based on morphological variation, which can be a

91 highly biased metric of biodiversity. Molecular studies are also subject to biases, in that it

92 can be difficult to establish whether a lack of genetic divergence reflects past or current

93 faunal connectivity (Clark et al., 2010; Miller et al., 2010). It is therefore important to

94 integrate taxonomic and biogeographical approaches when considering questions of faunal

95 isolation (Castelin et al., 2010). Characterizing these faunal assemblages is becoming

96 increasingly important for conservation, as seamounts can be targets of commercial mining

97 and fishing (e.g. Clark et al., 2010; Williams et al., 2010; Schlacher et al., 2014).

$98 \quad$ Chrysogorgia Duchassaing \& Michelotti, 1864 is a relatively diverse genus of

99 Octocorallia (Cnidaria, Anthozoa). It is globally distributed, and is found both on slopes and

100 on seamounts, where it can be locally very abundant (Watling et al., 2011). The

101 bathymetric range of Chrysogorgia is extremely large (Pante et al., 2012a, and references

102 therein), and encompasses the entire depth range of catalogued seamount summits and

103 slopes (Stocks, 2009). In addition, the genus appears to be monophyletic based on current

104 data (Pante et al., 2012a), offering opportunities for specific hypotheses about the

105 historical biogeography of species and species groups to be tested. Finally, the relative

106 congruence between morphotypes and mitochondrial $m t M u t S$ haplotypes described in four

107 North Atlantic species suggests that endemism can be investigated reliably at the species

108 level (Pante \& Watling, 2012). This result was recently confirmed by comparing genome-

109 scale data to $\mathrm{mtMutS}$ haplotypes (Pante et al., 2014). 
110 Based on these characteristics, Chrysogorgia offers a model system that is well

111 suited to estimating species endemism at different spatial scales, across the spectrum of

112 seamount environments (e.g. depth range or geological origin) and geographical locations

113 (e.g. latitude or isolation from continental margins) in a phylogenetically comprehensive

114 manner. Here, we investigate the geographical distribution of Chrysogorgia species from

115 seamount and non-seamount environments in the south-western Pacific, and contrast the

116 patterns of species distribution with those observed in the north-western Atlantic (Thoma

117 et al., 2009). To the best of our knowledge, this is the first study to look at the seamount-

118 scale endemism of a genus in different ocean basins.

120 MATERIALS AND METHODS

\section{Sampling and genotyping}

122 Specimens from the New Caledonian exclusive economic zone were collected during the

123 Muséum national d'Histoire naturelle (MNHN) / Institut de Recherche pour le

124 Développement (IRD) Terrasses and ExBoDi cruises of 2008 and 2011 on the NR, LR,

125 eastern slope of New Caledonia, and Matthew and Hunter Islands (MH) (Figs 1 \& 2, and see

126 Appendices S1 \& S2 in Supporting Information). The Terrasses and ExBoDi cruises are part

127 of a long-term research endeavour - the Tropical Deep-Sea Benthos (TDSB) program

128 (Bouchet et al., 2008; details of the cruises are available at

129 http://expeditions.mnhn.fr/program/tropicaldeep-seabenthos) - and relied on the

130 combined use of a beam trawl and a dredge to maximize the types of substrates and faunal

131 diversity collected. During the Terrasses cruise, 256 Chrysogorgia colonies were collected,

132213 of which were successfully genotyped (see below). An additional 439 and 421 colonies

133 were collected and genotyped, respectively, during the ExBoDi cruise. Specimens from

134 other cruises in the Pacific (including the TDSB cruises BIOPAPUA, EBISCO, MADEEP,

135 Norfolk 2, PAPUA NIUGINI, Salomon 1, Salomon 2, SMIB 4 and TAIWAN2013) provided

136 additional specimens for biogeographical comparisons ( $n=133$; Appendix S1). For

137 comparison, the study of Thoma et al. (2009) in the north-western Atlantic included 24

138 Chrysogorgia colonies among 188 octocorals. Sampling maps (Figs 1 \& 2) were made with

139 MARMAP (Pante \& Simon-Bouhet, 2013; R Core Team, 2014). 
Specimens were preserved in 80-100\% ethanol or RNAlater (Ambion , Austin, TX,

141 USA), or frozen at $-80^{\circ} \mathrm{C}$. Protocols for DNA extraction, PCR and sequencing are detailed in

142 Pante et al. (2012b). The 5' region of $m t M u t S$ was PCR-amplified using the primers

143 ND4L2475F and MUT3458R. For specimens with sheared DNA template, internal primers

144 were used (Pante et al., 2012a). Haplotypes were defined as unique mtMutS sequences, as

145 described in Thoma et al. (2009).

147 Evaluation of putative endemism, haplotype richness and sampling biases

148 Previous work in the north-western Atlantic that compared genetic variability with

149 morphological data suggested that mtMutS haplotypes had the power to resolve species of

150 Chrysogorgia, at least at a regional scale (Pante \& Watling, 2012), although the number of

151 haplotypes studied (four) was relatively small. It is therefore possible that, among our

152 Pacific samples, a single haplotype may represent multiple species of Chrysogorgia,

153 reducing our power to detect narrow geographical ranges (e.g. Baco \& Cairns, 2012). To

154 test whether unrecognized species diversity significantly affects our estimates of

155 connectivity between island slopes and seamounts, we performed computer simulations in

156 which haplotypes were split into two species of equivalent biogeography (Appendix S2).

157 To test the hypothesis that seamounts and island slopes harbour different species,

158 we analysed the site $\times$ haplotype matrix using non-metric multidimensional scaling (NMDS;

159 Kruskal, 1964a,b) and analysis of similarities (ANOSIM; Clarke, 1993). Sites are groups of

160 stations as presented in Fig. 2 and Appendix S1. We also grouped sites into five regions

161 (Fig. 2) to perform hierarchical clustering. Jaccard's index was used to compute distance

162 matrices from presence/absence data, because dredging and trawling are semiquantitative

163 sampling methods that may not capture the true abundance of organisms. Analyses were

164 performed in R using the package VEGAN 2.2-1 (Oksanen et al., 2015).

165 To test the hypothesis that seamounts harbour more endemics than island slopes,

166 we looked for species that were limited to individual seamounts and seamount chains. We

167 completed this qualitative survey by parsimony analysis of endemicity (PAE; Rosen \&

168 Smith, 1988). This method relies on parsimony to infer the relationship among sites, based

169 on their shared haplotypes. Sampling sites were grouped by region (slope, NR, southern LR, 
170 northern LR and MH), for which species occurrence was coded as 0 (absent), 1 (present at

171 one site) or 2 (present at more than one site). A 'zero vector' containing no species was

172 included in the region $\times$ haplotype data matrix to polarize characters (Morrone, 1994). The

173 most parsimonious tree was searched using nearest-neighbour interchange

174 rearrangements, and 1000 independent replicates were run. The consistency index (CI)

175 and retention index (RI) were calculated to evaluate how well the haplotype distribution

176 data fitted the most parsimonious tree (i.e. the degree of homoplasy). PAE was performed

177 in R using the package PHANGORN (Schliep, 2011).

178 To test the hypothesis that seamount communities are richer than island-slope

179 communities, haplotype richness was estimated using sample-based rarefaction, because

180 the total numbers of individuals and stations sampled varied among localities (Gotelli \&

181 Colwell, 2001). Estimated species richness (as computed in Colwell et al., 2012) was scaled

182 both using samples (Colwell et al., 2012) and using individuals (Gotelli \& Colwell, 2001), in

183 order to ease interpretation. Computations were performed in EsTIMATES 9.0 (Colwell,

184 2013). No rarefaction analysis was performed on the north-western Atlantic data, because

185 specimen collection during dives was non-random. Similarly, data from NR collected on

186 TDSB cruises prior to the Terrasses cruise (Bouchet et al., 2008) were not used in the

187 rarefaction analysis, because their sampling of Chrysogorgia was more qualitative than

188 quantitative.

189 Finally, we tested whether mtMutS haplotypes that share a distributional pattern

190 (specialist on seamounts or island slopes, or generalist) are phylogenetically close. To do

191 so, we inferred the phylogenetic relationships of all the known Pacific haplotypes by

192 building a median-joining haplotype network (http://popart.otago.ac.nz/, Bandelt et al.,

193 1999). We also ran one-level analyses of molecular variance (AMOVA; Excoffier et al., 1992)

194 in ARLEQuin 3.5 (Excoffier \& Lischer, 2010) on the data from the Terrasses and ExBoDi

195 cruises to partition the molecular variance (1) among seamount and slope groups and (2)

196 among depth groups (Kimura two-parameter distance matrix, gamma null, 10,000

197 permutations; Kimura, 1980). 
RESULTS

\section{Chrysogorgia biogeography on seamounts and slope of New Caledonia}

201 Chrysogorgia was found on the slope of New Caledonia, on the NR and LR, and on the slope 202 of MH, over most of the geographical and bathymetric range sampled during the Terrasses 203 and ExBoDi cruises. Out of 261 stations sampled (99 and 162 for Terrasses and ExBoDi, 204 respectively; Appendix S2), 74 recovered Chrysogorgia, 49 (66\%) of which were sampled

205 by dredging, reflecting the preference of Chrysogorgia for hard substrates. This proportion 206 was consistent across slope and seamount stations. Over the 74 stations containing Chrysogorgia colonies, 31 haplotypes were detected from 71 stations (specimens from three stations could not be sequenced), eight of which were represented by single colonies (Appendix S1). Most haplotypes (52\%) were represented by fewer than 10 specimens; 33 of the 71 stations contained multiple haplotypes. The most diverse stations (CP3898 and

211 DW3855 on LR) contained 10 haplotypes. Most haplotypes were found in the 200-600 m

212 depth range, a bathymetric zone that has been extensively sampled (Fig. 3).

213 Of the 31 haplotypes, five were found exclusively on the slope, 16 exclusively on

214 seamounts (19 if MH is included), and only six haplotypes were shared between the slope

215 and the seamounts of the NR and LR (seven including MH); 20 haplotypes were sampled on

216 LR, 9 of which were sampled nowhere else during the Terrasses and ExBoDi cruises. Only

217 five haplotypes were found on both seamount chains. Seamount-level endemism was 218 detected for 14 haplotypes, but five of these were observed only once each. Only three 219 relatively well-sampled haplotypes were each restricted to one seamount (haplotypes 11,

22024 and 27 on LR; $n \geq 20$ ). Haplotype 11 was sampled at especially great depths (750-

$221990 \mathrm{~m}$ ); if this taxon were indeed restricted to these depths, it could explain why we did

222 not observe it elsewhere, most stations being shallower. Haplotypes 24 and 27, in contrast,

223 were restricted to one seamount but were within the depth range of most sampling 224 stations (240-345 m).

225 The abundances of the seven haplotypes shared between slopes and seamounts

226 varied widely. To investigate whether species distributed across these habitats are found in 227 different densities, we calculated the proportion of stations containing each of the seven 228 haplotypes for slopes and seamounts, and sorted these proportions into vectors of high- 
229 density and low-density occurrences. If haplotypes shared between these environments do 230 not differ in their relative abundances, we expect the difference between these vectors to

231 be non-significant. This was not the case (paired Wilcoxon signed rank test: $V=0, P=$

232 0.016). For example, haplotype 23 was found at 5 of the 42 seamount stations where

233 Chrysogorgia was collected and only at one station (out of 29) on the slope.

234 Seamount regions did not group together under hierarchical clustering. Rather, the

235 slope region clustered with seamounts of the northern LR and MH, whereas the assemblage

236 of the NR and southern LR grouped together. NMDS recovered a weak association of sites

237 based on habitat (i.e. seamounts versus slope) (Fig. 4; ANOSIM $R$-statistic $=0.02, P=0.367$ ),

238 and a stronger association of sites of similar depth $(<400 \mathrm{~m}, 400-600 \mathrm{~m}, \geq 600 \mathrm{~m}$; ANOSIM

$239 R$-statistic $=0.22 ; P=0.048)$.

240 Rarefaction curves suggest that seamounts are more haplotype-rich than the south-

241 eastern slope of New Caledonia (Fig. 5). We observed 12 haplotypes in 181 individuals

242 from 101 slope stations. For comparison, rarefaction of the seamount data recovered 18

243 haplotypes from 180 individuals, and 23 haplotypes from 101 stations. These richness

244 estimates are relatively well supported statistically, as little (individual-scaled rarefaction)

245 or no (sample-scaled rarefaction) overlap in 95\% confidence intervals was observed. This

246 pattern (seamounts being richer than the slope) is largely driven by the richness observed

247 on southern LR seamounts (a total of 17 haplotypes). No rarefaction curve reached an

248 asymptote, suggesting that more haplotypes would be discovered with additional sampling.

249 The most parsimonious tree produced by the PAE (score of $45, \mathrm{CI}=0.89, \mathrm{RI}=0.5$ )

250 nested groups mostly according to geography (Fig. 6). PAE lumped stations on NR and the

251 southern LR together, this clade comprising 11 of the 31 detected haplotypes (35\%). The

252 slope was sister to this clade, forming a group sheltering 17 endemics, i.e. over half of the

253 total haplotype richness. Haplotype 3 was the only haplotype to be shared across all five

254 regions, and seven haplotypes (2, 8, 9, 10, 16, 19 and 23) were shared by different clades

255 (homoplastic haplotypes). Even though there are haplotypes shared between slope and

256 seamounts, the haplotype network showed some evidence of evolutionary subdivision

257 between these two groups (Fig. 7). This qualitative result was confirmed by the AMOVA,

258 which suggests that the amount of genetic variance partitioned between groups (8.5\%) is

259 larger than expected by chance $(P=0)$. However, the amount of genetic variance explained 
260 by depth stratification was 3.4 times greater (variance component, 28.8\%; $P$ = 0; see

261 Appendix S3).

\section{Regional and global haplotype distributions}

264 As reported in Thoma et al. (2009), the geographical distribution of haplotypes across the

265 New England Seamounts (NES) and Corner Seamounts (CS) was accompanied by wide

266 faunal connections with the Azores, the bathyal slope of the Bahamas, and Hawaii. Some

267 haplotypes collected during the Terrasses and ExBoDi cruises had wide distributions within

268 the Pacific, but none of them were observed in the Atlantic. For example, eight haplotypes

269 occurring in New Caledonia were collected in Papua New Guinea (PNG) (haplotypes 5, 7, 8,

2709 9, 10, 16, 22 and 30; Pante et al., 2012b). Three of these (haplotypes 7, 10 and 30) were

271 collected on Sanguma Seamount $\left(5.42^{\circ} \mathrm{S}, 154.02^{\circ} \mathrm{E}\right)$, the others coming from the PNG

272 island slopes. None of these haplotypes were restricted to a single seamount peak, but four

273 were restricted to seamounts (haplotypes 7, 10, 16 and 30; haplotype 22 being found

274 exclusively on the slope, and haplotypes 5, 8 and 9 on both slope and seamounts).

275 Haplotype 7, restricted to the seamounts of NR and LR, was also sampled on Nova Bank

276 Seamount (780 km west of New Caledonia; 330-340 m depth), from a depth zone

277 consistent with the bathymetric range observed on NR for this haplotype (300-390 m),

278 deeper on a seamount off Taiwan (517-573 m), and on slopes and Sanguma Seamount in

279 PNG (369-860 m). Similarly, a single colony of haplotype 12 was collected during the

280 Terrasses and ExBoDi cruises. We found a specimen with an identical $m t M u t S$ sequence and

281 congruent morphology from the south-west of the Kermadec Ridge (north-east of New

282 Zealand). This haplotype is an example of a rare but widespread species. Interestingly,

283 haplotype 9 appeared to have a very restricted distribution on the south-eastern slope of

284 New Caledonia, but a specimen with an identical mtMutS sequence and with congruent

285 gross morphology was sampled in the Solomon Islands during a TDSB cruise. This

286 haplotype was also sampled in Hawaii (Middle Bank) and the Aleutian Islands (Alaska). The

287 broad geographical distribution of some haplotypes points to the crucial role of sampling in

288 assessing endemism. Haplotype 9, for instance, was the fourth most frequently collected

289 taxon in New Caledonia, and was exclusively sampled on the south-western slope of the 
290 Isle of Pines $(n=45)$ and MH $(n=1)$. This haplotype was, however, also sampled in the

291 Solomon Islands, over $1500 \mathrm{~km}$ from the Isle of Pines.

\section{DISCUSSION}

294 Correspondence between haplotypes and nominal species

295 A major issue for studies of coral biogeography and connectivity, this one included, is the

296 difficulty of separating historical from contemporary connectivity. Wide geographical

297 distributions could reflect either strong dispersal capabilities or ancient connections

298 between ocean basins. We recently used genome-wide SNP (single nucleotide

299 polymorphism) data to evaluate the hypothesis that mitochondrial $m t M u t S$ haplotypes can

300 reliably represent species-level lineages, and found good congruence (67\%) between

301 mtMutS-based species delimitation and genomic divergence (Pante et al., 2014). Specimens

302 characterized by haplotypes 2, 8 and 13 may belong to a single species. Conversely, the

303 New Caledonian specimens with haplotype 7 where phylogenetically distinct from the ones

304 sampled in PNG, suggesting that colonies bearing this haplotype may belong to at least two

305 species. Nevertheless, our simulation data (Appendix S2) suggest that, at the community

306 level, underestimation of species richness due to lack of genetic resolution only has a

307 moderate impact on the overall measure of faunal connectivity between slopes and

308 seamounts. In addition, the apparent lack of geographical structuring on the NES and CS

309 (Thoma et al., 2009) is in sharp contrast with the data from New Caledonia. Our data are

310 therefore useful in a comparative biogeographical framework.

312 Chrysogorgia on seamounts and slope

313 The apparent lack of endemism of chrysogorgiid corals on Atlantic seamounts is consistent

314 with recent biogeographical and molecular studies of other seamount fauna (reviewed in

315 Clark et al., 2010; Rowden et al., 2010a; Schlacher et al., 2010). The overall consensus is

316 that Pacific seamounts do not harbour significantly more endemic species than other,

317 equivalent deep-sea habitats (Samadi et al., 2006; O'Hara, 2007; Rowden et al., 2010b). For

318 instance, no endemism was detected among bamboo corals based on mitochondrial

319 sequence data (Smith et al., 2004). Similarly, Miller et al. (2010) recently reported on the 
320 genetic connectivity among nine species of corals (six scleractinians and three

321 antipatharians) and found weak evidence for isolation by distance and barriers to dispersal

322 between seamount peaks in the south-western Pacific. Our results are in contrast with

323 those patterns, as up to 29\% of Chrysogorgia haplotypes sampled more than once could be

324 restricted to a single seamount. Durand Reef in particular appeared to be a hotspot of

325 diversity and endemism, with 14 haplotypes, half of which were observed nowhere else.

326 The difference between our study and the studies of Smith et al. (2004) and Miller et al.

327 (2010), may lie in the overall depth range surveyed; Miller and colleagues used specimens

328 collected between 110 and $2136 \mathrm{~m}$ (median $542 \mathrm{~m}$, mean $721 \mathrm{~m}$ ), covering a much deeper

329 range than we have here (70-1180 m; median 456 m, mean $497 \mathrm{~m})$. The haplotypes

330 reported by Smith et al. (2004) were also mostly restricted to waters deeper than $500 \mathrm{~m}$,

331 some extending as deep as $3000 \mathrm{~m}$. These observations are consistent with the wide

332 geographical distribution observed in the Atlantic, where sampling was mostly performed

333 at depths between 1500 and $2000 \mathrm{~m}$. In fact, Pante \& Watling (2012) noted that none of the

334 Chrysogorgia species previously detected on the slope of the north-western Atlantic were

335 detected on the NES and CS, and that the sampling depth of these two species pools barely

336 overlapped (see Fig. 14 in Pante \& Watling, 2012).

338 Geographical distribution structured by depth

339 The effect of depth on the distribution (reviewed in Etter \& Rex, 2010) and genetic

340 structure (e.g. France \& Kocher, 1996; Zardus et al., 2006; Cho \& Shank, 2010; Jennings et

341 al., 2013) of deep-sea organisms has long been known, and is gaining recognition for corals

342 (Eytan et al., 2009; Baco \& Cairns, 2012; Quattrini et al., 2013, 2015; Doughty et al., 2014).

343 Environmental conditions such as pressure, temperature, dissolved oxygen and habitat

344 heterogeneity (to name a few; Gage \& Tyler, 1991) can change significantly with depth,

345 resulting in vertical zonation of benthic communities. These effects are, however, still little

346 characterized for seamount fauna. McClain et al. (2010), investigating the structure of

347 invertebrate and fish communities on Davidson Seamount in the north-eastern Pacific,

348 found that assemblage composition, rather than diversity or density, changed with depth

349 (1246-3656 m). In particular, they reported that octocorals showed significant species 
350 turnover between depths, which accounted for a significant proportion of the variation

351 observed. In our study, differences in geographical and bathymetric haplotype

352 distributions might be due to differences in the environmental setting, such as the sampled

353 depth regimes, which overlapped only slightly (deepest NR/LR station: $1130 \mathrm{~m}$; shallowest

354 NES/CS station: $823 \mathrm{~m}$ ). Etter et al. (2005) showed that genetic differentiation decreases

355 with increasing depth in populations of deep-sea bivalves. Likewise, Bradbury et al. (2008)

356 found a positive correlation between depth and pelagic larval duration, and a negative

357 correlation between depth and amounts of genetic structure in marine fishes. Our results

358 may therefore suggest that the stratification of Chrysogorgia haplotypes decreases with

359 depth. This hypothesis, which implies that environmental conditions are less structuring at

360 deeper depths, cannot be rigorously tested across ocean basins with the data at hand, but

361 preliminary observations from our data suggest more complex patterns, because the

362 deepest haplotypes observed on the LR and NR are not necessarily the most geographically

363 widespread (e.g. haplotypes 12, 30 and 31, although sampling was less intensive below

$364800 \mathrm{~m}$ ) and some shallow haplotypes are widely distributed (e.g. haplotypes 3 and 4; Fig. 3,

365 Appendix S1). The stratification of haplotypes may therefore decrease below a depth of

$3661130 \mathrm{~m}$; this could be tested by deeper sampling on the LR and NR.

368 Regional and global haplotype distributions

369 Chrysogorgia species pools from the Atlantic and Pacific Oceans seem to be characterized

370 by different distributional ranges and diversity patterns. The Terrasses and ExBoDi

371 haplotypes that were found outside the New Caledonian exclusive economic zone were

372 mostly limited to the south-west Pacific region (from Taiwan to the Kermadec Ridge, a

373 range of approximately $59^{\circ}$ of latitude and $61^{\circ}$ of longitude; with the exception of

374 haplotype 9, the distribution of which extends to Hawaii). In contrast, all chrysogorgiid

375 genera (Chrysogorgia, Iridogorgia, Radicipes and Metallogorgia) sampled on the Atlantic

376 NES and CS contain haplotypes that are represented in the Pacific (Thoma et al., 2009). In

377 other words, the Atlantic chrysogorgiids appear to have an overall geographical range that

378 is wider than that of New Caledonian chrysogorgiids. On the other hand, Pacific

379 Chrysogorgia were characterized by high levels of patchiness, rarity and haplotypic 
380 diversity. Rarity and patchiness were observable at two levels. At the local scale, the

381 number of colonies sampled at a single station was highly variable. For instance, at stations

382 with Chrysogorgia, abundance varied from 1 to 109 colonies, with an average of 9 and a

383 standard deviation of 18. At the regional scale, some haplotypes categorized as rare in New

384 Caledonia were nevertheless sampled very far apart, such as in New Zealand, Papua New

385 Guinea or Taiwan. These patterns of rarity and patchiness of deep New Caledonian fauna

386 have also been observed in gastropods (Castelin et al., 2011). These observations suggest

387 that the sampling effort necessary to accurately describe the distribution of Chrysogorgia

388 haplotypes in the Pacific is far greater than in the Atlantic. Nevertheless, sampling over 760

389 Pacific specimens provided data that emphasize the importance of depth, rarity and

390 patchiness in structuring these communities, both on seamounts and on oceanic slopes.

392 ACKNOWLEDGEMENTS

393 We thank the PIs and crew of the various research expeditions that allowed us to collect

394 Chrysogorgia, as well as to our colleagues at the MNHN, IRD, the University of Louisiana at

395 Lafayette and the University of Hawaii. We thank two anonymous referees for their

396 comments. Detailed acknowledgements on sampling and funding information are given in

397 Appendix S2.

\section{REFERENCES}

401 Allain, V., Kerandel, J.-A., Andréfouët, S., Magron, F., Clark, M., Kirby, D.S. \& Muller-Karger, 402 F.E. (2008) Enhanced seamount location database for the western and central Pacific

403 Ocean: screening and cross-checking of 20 existing datasets. Deep-Sea Research Part I:

404 Oceanographic Research Papers, 55, 1035-1047.

405 Baco, A.R. \& Cairns, S.D. (2012) Comparing molecular variation to morphological species

406 designations in the deep-sea coral Narella reveals new insights into seamount coral

407 ranges. PLoS ONE, 7, e45555.

408 Bandelt, H.J., Forster, P. \& Röhl, A. (1999) Median-joining networks for inferring

409 intraspecific phylogenies. Molecular Biology and Evolution, 16, 37-48. 
410 Bouchet, P., Héros, V., Lozouet, P. \& Maestrati, P. (2008) A quarter-century of deep-sea

411 malacological exploration in the South and West Pacific: Where do we stand? How far to 412 go? Tropical Deep-Sea Benthos 25 (ed. by V. Héros, R.H. Cowie and P. Bouchet). Mémoires

413 du Muséum national d'Histoire naturelle, 196, 9-40.

414 Bradbury, I.R., Laurel, B., Snelgrove, P.V.R., Bentzen, P. \& Campana, S.E. (2008) Global

415 patterns in marine dispersal estimates: the influence of geography, taxonomic category

416 and life history. Proceedings of the Royal Society B: Biological Sciences, 275, 1803-1809.

417 Castelin, M., Lambourdière, J., Boisselier, M.-C., Lozouet, P., Couloux, A., Cruaud, C. \& Samadi,

418 S. (2010) Hidden diversity and endemism on seamounts: focus on poorly dispersive

419 neogastropods. Biological Journal of the Linnean Society, 100, 420-438.

420 Castelin, M., Puillandre, N., Lozouet, P., Sysoev, A., Richer de Forges, B. \& Samadi, S. (2011)

421 Molluskan species richness and endemism on New Caledonian seamounts: are they

422 enhanced compared to adjacent slopes? Deep-Sea Research Part I: Oceanographic

423 Research Papers, 58, 637-646.

424 Cho, W. \& Shank, T.M. (2010) Incongruent patterns of genetic connectivity among four

425 ophiuroid species with differing coral host specificity on North Atlantic seamounts.

426 Marine Ecology, 31 (Suppl. 1), 121-143.

427 Clark, M.R., Rowden, A.A., Schlacher, T., Williams, A., Consalvey, M., Stocks, K.I., Rogers, A.D.,

428 O'Hara, T.D., White, M., Shank, T.M. \& Hall-Spencer, J.M. (2010) The ecology of

429 seamounts: structure, function, and human impacts. Annual Review of Marine Science, 2 ,

$430 \quad 253-278$.

431 Clark, M.R., Schlacher, T.A., Rowden, A.A., Stocks, K.I. \& Consalvey, M. (2012) Science

432 priorities for seamounts: research links to conservation and management. PLoS ONE, 7,

433 e29232.

434 Clarke, K. (1993) Non-parametric multivariate analyses of changes in community structure.

435 Australian Journal of Ecology, 18, 117-143.

436 Colwell, R.K. (2013) EstimateS: statistical estimation of species richness and shared species

437 from samples. Version 9. Available at: http://purl.oclc.org/estimates.

438 Colwell, R.K., Chao, A., Gotelli, N.J., Lin, S.-Y., Mao, C.X., Chazdon, R.L. \& Longino, J.T. (2012)

439 Models and estimators linking individual-based and sample-based rarefaction,

440 extrapolation and comparison of assemblages. Journal of Plant Ecology, 5, 3-21. 
441 Doughty, C.L., Quattrini, A.M. \& Cordes, E.E. (2014) Insights into the population dynamics of 442 the deep-sea coral genus Paramuricea in the Gulf of Mexico. Deep-Sea Research Part II:

443 Topical Studies In Oceanography, 99, 71-82.

444 Ekman, S. (1953) Zoogeography of the sea. Sidgwick and Jackson, London.

445 Etnoyer, P.J., Wood, J. \& Shirley, T.C. (2010) How large is the seamount biome?

446 Oceanography, 23, 206-209.

447 Etter, R.J. \& Rex, M.A. (2010) Deep-sea biodiversity: pattern and scale. Harvard University 448 Press, Cambridge, MA.

449 Etter, R.J., Rex, M.A., Chase, M.R. \& Quattro, J.M. (2005) Population differentiation decreases 450 with depth in deep-sea bivalves. Evolution, 59, 1479-1491.

451 Excoffier, L. \& Lischer, H.E.L. (2010) Arlequin suite ver 3.5: a new series of programs to 452 perform population genetics analyses under Linux and Windows. Molecular Ecology 453 Resources, 10, 564-567.

454 Excoffier, L., Smouse, P.E. \& Quattro, J.M. (1992) Analysis of molecular variance inferred 455 from metric distances among DNA haplotypes: application to human mitochondrial DNA 456 restriction data. Genetics, 131, 479-491.

457 Eytan, R.I., Hayes, M., Arbour-Reily, P., Miller, M. \& Hellberg, M.E. (2009) Nuclear sequences 458 reveal mid-range isolation of an imperilled deep-water coral population. Molecular 459 Ecology, 18, 2375-2389.

460 France, S.C. \& Kocher, T.D. (1996) Geographic and bathymetric patterns of mitochondrial 461 16S rRNA sequence divergence among deep-sea amphipods, Eurythenes gryllus. Marine 462 Biology, 126, 633-643.

463 Gage, J.D. \& Tyler, P.A. (1991) Deep-sea biology: a natural history of organisms at the deep464 sea floor. Cambridge University Press, Cambridge, UK.

465 Gotelli, N.J. \& Colwell, R.K. (2001) Quantifying biodiversity: procedures and pitfalls in the 466 measurement and comparison of species richness. Ecology Letters, 4, 379-391.

467 Hall-Spencer, J., Rogers, A., Davies, J. \& Foggo, A. (2007) Deep-sea coral distribution on 468 seamounts, oceanic islands, and continental slopes in the Northeast Atlantic. Bulletin of 469 Marine Science, 81 (Suppl. 1), 135-146.

470 Howell, K.L., Mowles, S.L. \& Foggo, A. (2010) Mounting evidence: near-slope seamounts are 471 faunally indistinct from an adjacent bank. Marine Ecology, 31(Suppl. 1), 52-62. 
472 Hubbs, C.L. (1959) Initial discoveries of fish faunas on seamounts and offshore banks in the 473 eastern Pacific. Pacific Science, 13, 311-316.

474 Jennings, R.M., Etter, R.J. \& Ficarra, L. (2013) Population differentiation and species

475 formation in the deep sea: the potential role of environmental gradients and depth. PLoS 476 ONE, 8, e77594.

477 Kimura, M. (1980) A simple method for estimating evolutionary rates of base substitutions

478 through comparative studies of nucleotide-sequences. Journal of Molecular Evolution, 16, 479 111-120.

480 Kruskal, J.B. (1964a) Multidimensional scaling by optimizing goodness-of-fit to a nonmetric 481 hypothesis. Psychometrika, 29, 1-28.

483 Psychometrika, 29, 115-129.

484 Lundsten, L., Barry, J.P., Cailliet, G.M., Clague, D.A., DeVogelaere, A.P. \& Geller, J.B. (2009a)

485 Benthic invertebrate communities on three seamounts off southern and central

486 California, USA. Marine Ecology Progress Series, 374, 23-32.

487 Lundsten, L., McClain, C.R., Barry, J.P., Cailliet, G.M., Clague, D.A. \& DeVogelaere, A.P. (2009b)

488 Ichthyofauna on three seamounts off southern and central California, USA. Marine

489 Ecology Progress Series, 389, 223-232.

490 McClain, C.R. (2007) Seamounts: identity crisis or split personality? Journal of

491 Biogeography, 34, 2001-2008.

492 McClain, C.R., Lundsten, L., Ream, M., Barry, J. \& DeVogelaere, A. (2009) Endemicity,

493 biogeography, composition, and community structure on a Northeast Pacific seamount.

$494 \quad$ PLOS ONE, 4, e4141.

495 McClain, C.R., Lundsten, L., Barry, J. \& DeVogelaere, A. (2010) Assemblage structure, but not

496 diversity or density, change with depth on a northeast Pacific seamount. Marine Ecology, 49731 (Suppl. 1), 14-25.

498 Miller, K., Williams, A., Rowden, A.A., Knowles, C. \& Dunshea, G. (2010) Conflicting

499 estimates of connectivity among deep-sea coral populations. Marine Ecology, 31 (Suppl.

500 1), 144-157.

501 Morrone, J.J. (1994) On the identification of areas of endemism. Systematic Biology, 43, $502 \quad 438-441$. 
503 O'Hara, T.D. (2007) Seamounts: centres of endemism or species richness for ophiuroids?

$504 \quad$ Global Ecology and Biogeography, 16, 720-732.

505 Oksanen, J., Blanchet, F.G., Kindt, R., Legendre, P., Minchin, P.R., O’Hara, R.B., Simpson, G.L.,

506 Solymos, P., Stevens, M.H.H. \& Wagner, H. (2015) vegan: community ecology package.

507 Available at: http://cran.r-project.org/package=vegan.

508 Pante, E. \& Simon-Bouhet, B. (2013) marmap: a package for importing, plotting and

509 analyzing bathymetric and topographic data in R. PLoS ONE, 8, e73051.

510 Pante, E. \& Watling, L. (2012) Chrysogorgia from the New England and Corner Seamounts:

511 Atlantic-Pacific connections. Journal of the Marine Biological Association of the United

$512 \quad$ Kingdom, 92, 911-927.

513 Pante, E., France, S.C., Couloux, A., Cruaud, C., McFadden, C.S., Samadi, S. \& Watling, L.

514 (2012a) Deep-sea origin and in-situ diversification of chrysogorgiid octocorals. PLoS

515 ONE, 7, e38357.

516 Pante, E., Corbari, L., Thubaut, J., Chan, T.-Y., Mana, R., Boisselier, M.-C., Bouchet, P. \&

517 Samadi, S. (2012b) Exploration of the deep-sea fauna of Papua New Guinea.

518 Oceanography, 25, 214-225.

519 Pante, E., Abdelkrim, J., Viricel, A., Gey, D., France, S.C., Boisselier, M.-C., Samadi, S. (2014)

520 Use of RAD sequencing for delimiting species. Heredity, 114, 450-459.

521 doi:10.1038/hdy.2014.105

522 Parin, N.V., Mironov, A.N. \& Nesis, K.N. (1997) Biology of the Nazca and Sala y Gómez

523 submarine ridges, and outpost of the Indo-West Pacific fauna in the eastern Pacific

524 Ocean: composition and distribution of the fauna, its communities and history. Advances

525 in marine biology, Vol. 32, The biogeography of the oceans (ed. by J.H.S. Blaxter, A.J.

526 Southward, A.V. Gebruk, E.C. Southward and P.A. Tyler), pp. 145-242. Academic Press,

527 San Diego, CA.

528 Parker, T. \& Tunnicliffe, V. (1994) Dispersal strategies of the biota on an oceanic seamount:

529 implications for ecology and biogeography. Biological Bulletin, 187, 336-345.

530 Quattrini, A.M., Georgian, S.E., Byrnes, L., Stevens, A., Falco, R. \& Cordes, E.E. (2013) Niche

531 divergence by deep-sea octocorals in the genus Callogorgia across the continental slope

532 of the Gulf of Mexico. Molecular Ecology, 22, 4123-4140.

533 Quattrini, A.M., Baums, I.B., Shank, T.M., Morrison, C.L. \& Cordes, E.E. (2015) Testing the 
534 depth-differentiation hypothesis in a deepwater octocoral. Proceedings of the Royal 535 Society B: Biological Sciences, 282, 20150008. Doi:10.1098/rspb.2015.0008

536 R Core Team (2014) R: a language and environment for statistical computing. R Foundation

537 for Statistical Computing, Vienna, Austria. Available at: http://www.r-project.org/.

538 Richer de Forges, B., Koslow, J.A. \& Poore, G.C.B. (2000) Diversity and endemism of the

539 benthic seamount fauna in the southwest Pacific. Nature, 405, 944-947.

540 Rogers, A.D. (1994) The biology of seamounts. Advances in Marine Biology, 30, 305-350.

541 Rosen, B.R. \& Smith, A.B. (1988) Tectonics from fossils? Analysis of reef-coral and sea-

542 urchin distributions from late Cretaceous to Recent, using a new method. Geological

543 Society Special Publications, 37, 275-306.

544 Rowden, A.A., Dower, J.F., Schlacher, T.A., Consalvey, M. \& Clark, M.R. (2010a) Paradigms in 545 seamount ecology: fact, fiction and future. Marine Ecology, 31 (Suppl. 1), 226-241.

546 Rowden, A.A., Schnabel, K.E., Schlacher, T.A., Macpherson, E., Ahyong, S.T. \& Richer de

547 Forges, B. (2010b) Squat lobster assemblages on seamounts differ from some, but not

548 all, deep-sea habitats of comparable depth. Marine Ecology, 31 (Suppl. 1), 63-83.

549 Samadi, S., Bottan, L., Macpherson, E., Richer de Forges, B. \& Boisselier, M.-C. (2006)

550 Seamount endemism questioned by the geographic distribution and population genetic

551 structure of marine invertebrates. Marine Biology, 149, 1463-1475.

552 Schlacher, T.A., Rowden, A.A., Dower, J.F. \& Consalvey, M. (2010) Seamount science scales

553 undersea mountains: new research and outlook. Marine Ecology, 31 (Suppl. 1), 1-13.

554 Schlacher, T.A., Baco, A.R., Rowden, A.A., O'Hara, T.D., Clark, M.R., Kelley, C., Dower, J.F.

555 (2014) Seamount benthos in a cobalt-rich crust region of the central Pacific:

556 conservation challenges for future seabed mining. Diversity and Distributions, 20, 491-

$557 \quad 502$.

558 Schliep, K.P. (2011) phangorn: phylogenetic analysis in R. Bioinformatics, 27, 592-593.

559 Smith, P.J., McVeagh, S.M., Mingoia, J.T. \& France, S.C. (2004) Mitochondrial DNA sequence

560 variation in deep-sea bamboo coral (Keratoisidinae) species in the southwest and

561 northwest Pacific Ocean. Marine Biology, 144, 253-261.

562 Staudigel, H., Koppers, A.A.P., Lavelle, J.W., Pitcher, T.J. \& Shank, T.M. (2010) From the guest

563 editors. Oceanography, 23, 18-19.

564 Stocks, K.I. (2009) SeamountsOnline: an online information system for seamount biology. 
Available at: http://seamounts.sdsc.edu/.

566 Stocks, K.I. \& Hart, P.J.B. (2007) Biogeography and biodiversity of seamounts. Seamounts:

567 ecology, fisheries and conservation (ed. by T.J. Pitcher, T. Morato, P.J.B. Hart, M.R. Clark, N.

568 Haggan and R.S. Santos), pp. 255-281. Blackwell Publishing, Oxford, UK.

569 Thoma, J.N., Pante, E., Brugler, M.R. \& France, S.C. (2009) Deep-sea octocorals and

570 antipatharians show no evidence of seamount-scale endemism in the NW Atlantic.

$571 \quad$ Marine Ecology Progress Series, 397, 25-35.

572 Watling, L., France, S.C., Pante, E. \& Simpson, A. (2011) Biology of deep-water octocorals.

573 Advances in Marine Biology, 60, 41-122.

574 Wessel, P. (2007) Seamount characteristics. Seamounts: ecology, fisheries and conservation

575 (ed. by T.J. Pitcher, T. Morato, P.J.B. Hart, M.R. Clark, N. Haggan and R.S. Santos), pp. 1-25.

576 Blackwell Publishing, Oxford.

577 Wessel, P., Sandwell, D.T. \& Kim, S.-S. (2010) The global seamount census. Oceanography,

$578 \quad 23,24-33$.

579 Williams, A, Schlacher, T.A., Rowden, A.A., Althaus, F., Clark, M.R., Bowden, D.A., Stewart, R.,

580 Bax, N.J., Consalvey, M., Kloser, R.J. (2010) Seamount megabenthic assemblages fail to

581 recover from trawling impacts. Marine Ecology, 31 (Suppl. S1), 183-199.

582 Wilson, R. \& Kaufmann, R. (1987) Seamount biota and biogeography. Seamounts, islands,

583 and atolls (ed. by B.H. Keating, P. Fryer, R. Batiza and G.W. Boehlert), pp. 355-377.

584 Geophysical Monograph 43, American Geophysical Union, Washington, DC.

585 Yesson, C., Clark, M.R., Taylor, M.L. \& Rogers, A.D. (2011) The global distribution of

586 seamounts based on 30 arc seconds bathymetry data. Deep-Sea Research Part I:

587 Oceanographic Research Papers, 58, 442-453.

588 Zardus, J.D., Etter, R.J., Chase, M.R., Rex, M.A. \& Boyle, E.E. (2006) Bathymetric and

589 geographic population structure in the pan-Atlantic deep-sea bivalve Deminucula

590 atacellana (Schenck, 1939). Molecular Ecology, 15, 639-651. 
592 SUPPORTING INFORMATION

593 Additional Supporting Information may be found in the online version of this article:

594 Appendix S1 Excel table of Chrysogorgia specimens with biogeographical and haplotype 595 information.

596 Appendix S2 Supplemental text.

597 Appendix S3 Median-joining network for Pacific Chrysogorgia haplotypes, plotted by depth 598 and geography.

599

\section{BIOSKETCH}

601 Eric Pante and Scott C. France work on the evolution, biogeography and systematics of 602 marine organisms, particularly deep-sea corals. Sarah Samadi and her group investigate 603 faunal connectivity among benthic organisms of the deep tropical western Pacific Ocean. 604

605 Author contributions: E.P., S.C.F. and S.S. conceived the ideas; E.P., S.C.F. and S.S. (among 606 others) collected the specimens; E.P., D.G. and C.C. generated the genetic data; E.P. analysed 607 the data and wrote the paper; all authors approved the final version.

609 Editor: David Bellwood 


\section{FIGURE CAPTIONS}

612 Figure 1 World map with the two major sampling locations and the sampling locations of

613 specimens used in biogeographical comparisons. Samples used in previous studies are

614 plotted using different symbols. NES, New England Seamounts; CS, Corner Seamounts.

615 Figure 2 Bathymetric map of New Caledonia and parts of the Norfolk and Loyalty ridges. All

616 stations sampled during the Terrasses and ExBoDi cruises are plotted as grey squares.

617 Stations containing at least one Chrysogorgia colony are marked by black circles. Isobaths

618 are plotted every $500 \mathrm{~m}$ from 100 to $3000 \mathrm{~m}$. Slope stations were divided into three

619 geographically discrete areas for biogeographical analyses. The feature labelled '6756' is a

620 nameless seamount (Allain et al., 2008) adjacent to the New Caledonian slope. Although a

621 Chrysogorgia specimen was collected from this seamount, it could not be genotyped. LR,

622 Loyalty Ridge; NR, Norfolk Ridge.

623 Figure 3 Geographical (top) and bathymetric (bottom) distributions of the 31 haplotypes

624 sampled during the Terrasses and ExBoDi cruises. Minimum and maximum depths were

625 calculated based on the minimum and maximum depths of trawling and dredging stations

626 that contained Chrysogorgia. The colour of each bar represents the number of colonies

627 sampled for each haplotype ( $n$; see key in the bottom left corner). Haplotype number is

628 provided on top of each bar. LR, Loyalty Ridge; NR, Norfolk Ridge; MH, Matthew and Hunter

629 Islands.

630 Figure 4 (a) Hierarchical cluster analysis and (b) non-metric multidimensional scaling

631 (NMDS) based on Jaccard's dissimilarity between regions and sites. For NMDS, the symbol

632 size is proportional to the number of haplotypes recorded at each site, and different

633 symbols represent different mean depths (light grey, seamounts; dark grey, slope). Site

634 names and depth ranges $(\mathrm{m})$ are provided next to each symbol.

635 Figure 5 Haplotype richness on the south-eastern New Caledonian slope and seamounts of

636 the Norfolk Ridge (NR) and Loyalty Ridge (LR). Left: individual-scaled rarefaction curves.

637 Right: sample-scaled rarefaction curves. Upper panels: rarefied haplotype richness for all

638 regions. Lower panels: rarefied haplotype richness for seamounts and slopes, with 95\%

639 confidence envelopes. For each group, the total observed number of haplotypes is given in 640 parentheses. 
641 Figure 6 Parsimony analysis of endemicity (PAE). The dots placed on branches of the tree 642 represent haplotypes endemic to a clade (synapomorphic haplotypes), which can be 643 defined by one or several regions.

644 Figure 7 Median-joining network for all known Pacific Chrysogorgia haplotypes (left) and 645 Venn diagram showing the haplotype distribution among Pacific regions (right). Network:

646 mutational steps are represented by hashes on network branches; circle size is 647 proportional to sample size. A detailed list of sampling locations and networks drawn 648 according to depth and geography are available in Appendices S1 \& S3 of Supporting 649 Information.

650 


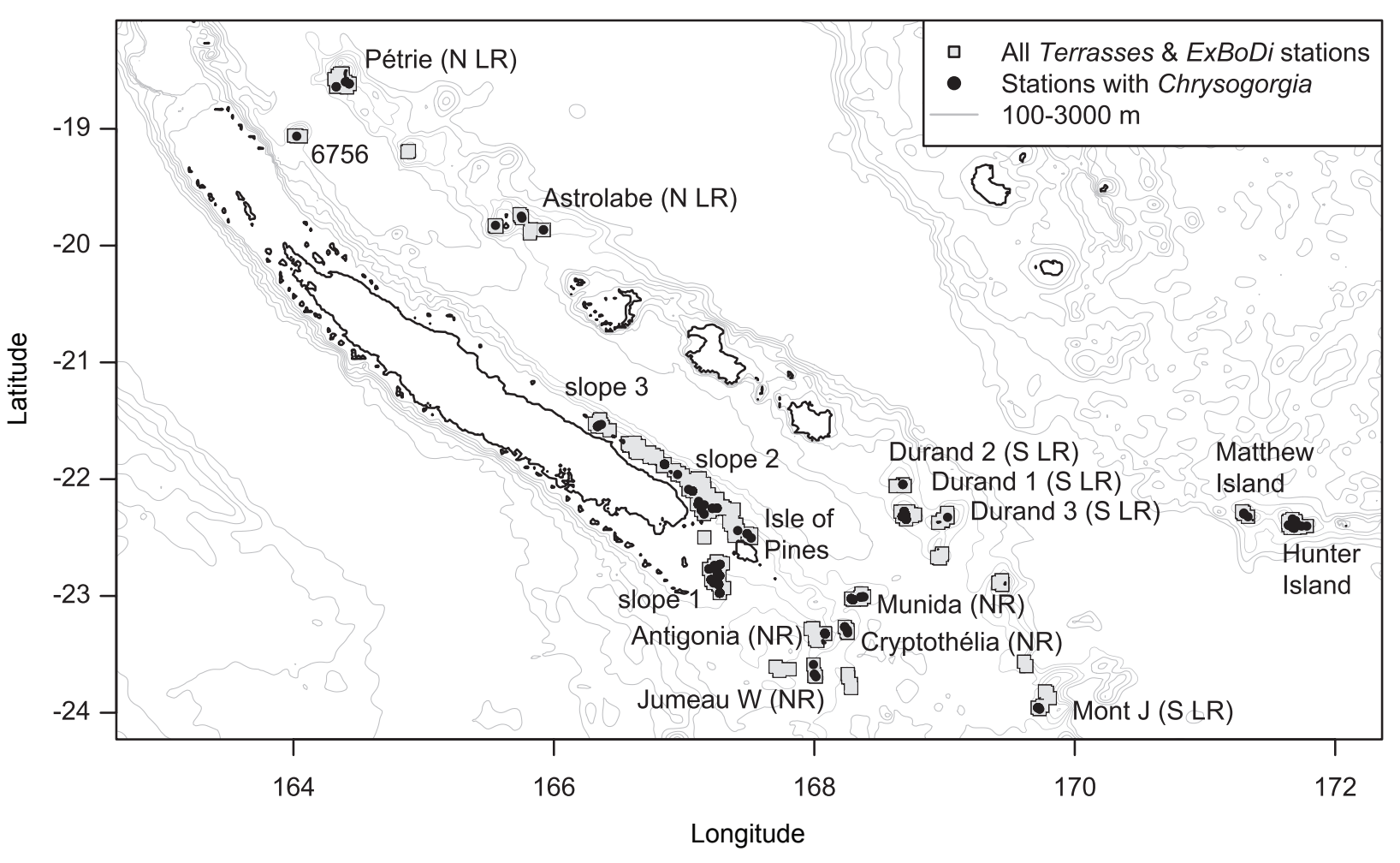


Matthew \& Hunter

(Matthew, Hunter)

\section{Slope}

(slope 1, 2, 3, Isle of Pines)

Northern Loyalty Ridge (Astrolabe, Pétrie)

\section{Norfolk Ridge}

- (Antigonia, Cryptothélia,

Jumeau W, Munida, Mont J)

Southern Loyalty Ridge (Durand 1, 2, 3)

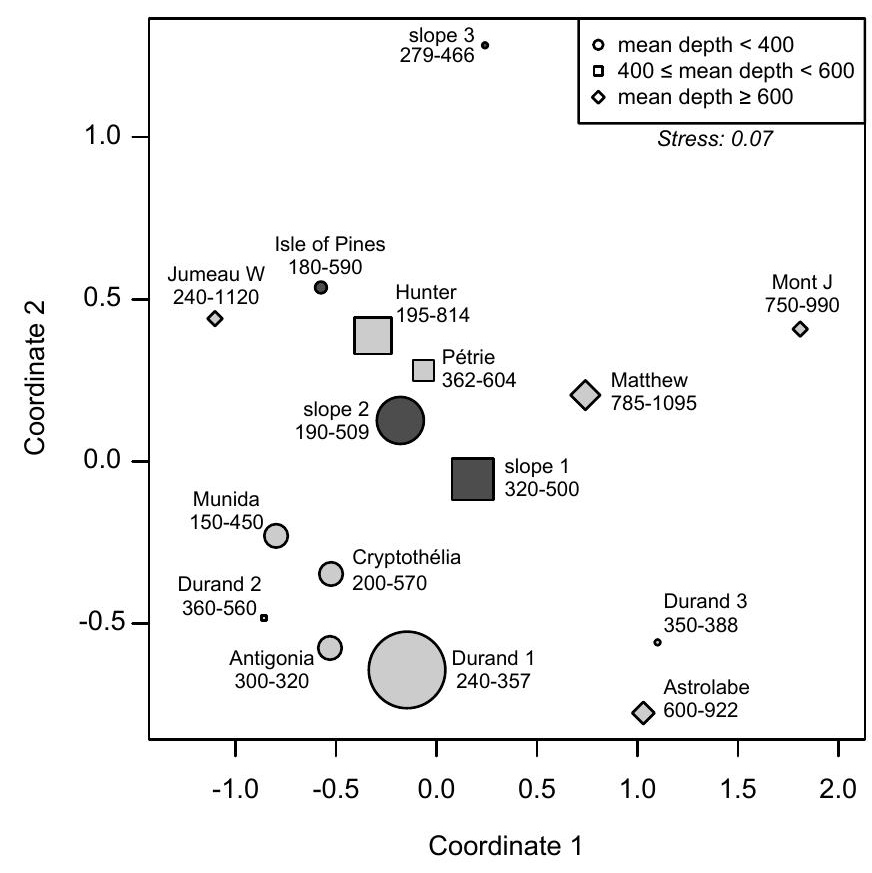

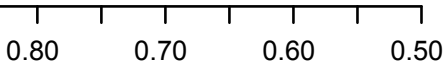

Jaccard's dissimilarity index 
Individual-scaled rarefaction
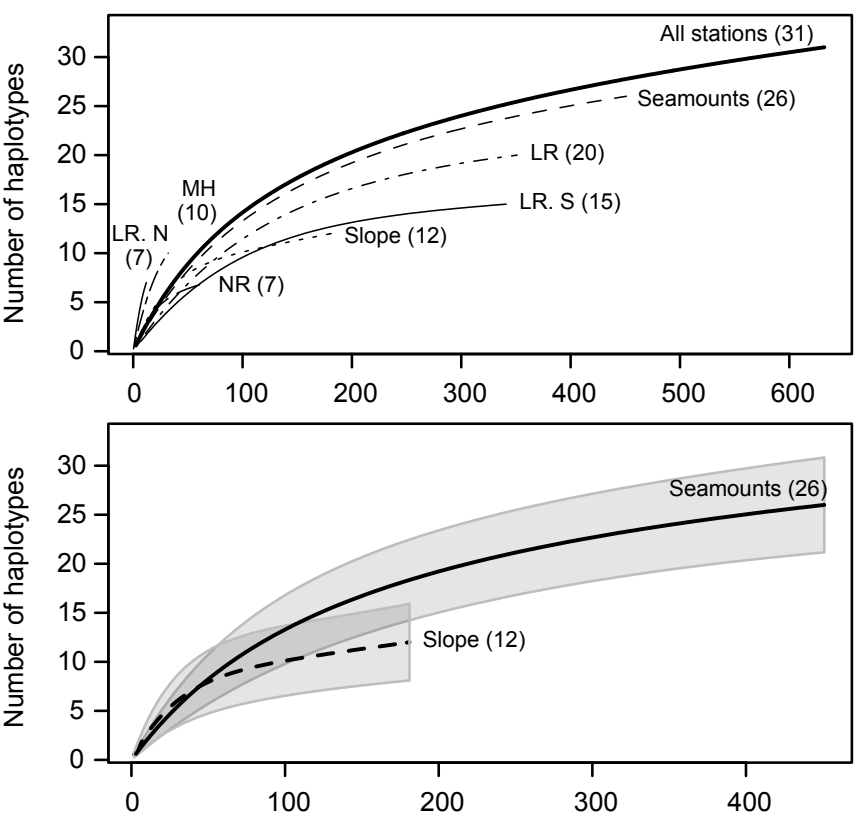

Number of individuals
Sample-scaled rarefaction
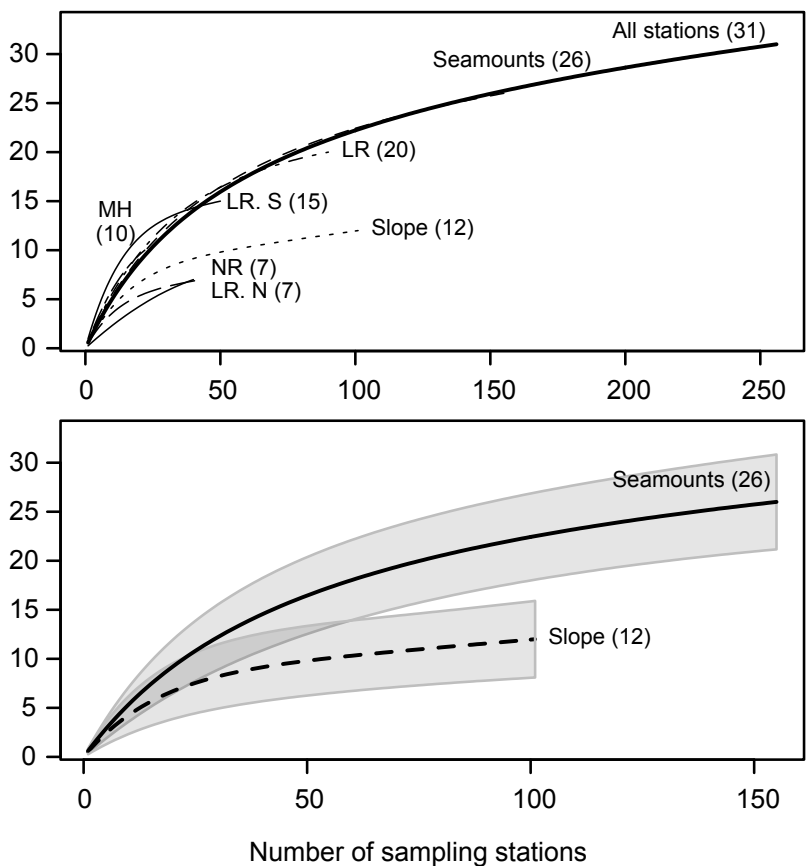
3031 Northern

Loyalty Ridge ( $N$ LR)

$171820 \quad$ Matthew \&

Hunter (MH)

$-4$

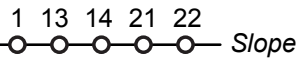

5

11242526272829 Southern

$\stackrel{6}{6} 12$

$7 \begin{array}{ll}7 & 15 \\ -0 & 0\end{array}$

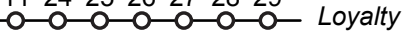
Ridge (S LR) 
(a)

New Caledonian seamount

Other Pacific seamount

- New Caledonian slope

- Other Pacific slope

Other Pacific feature (e.g. bank)

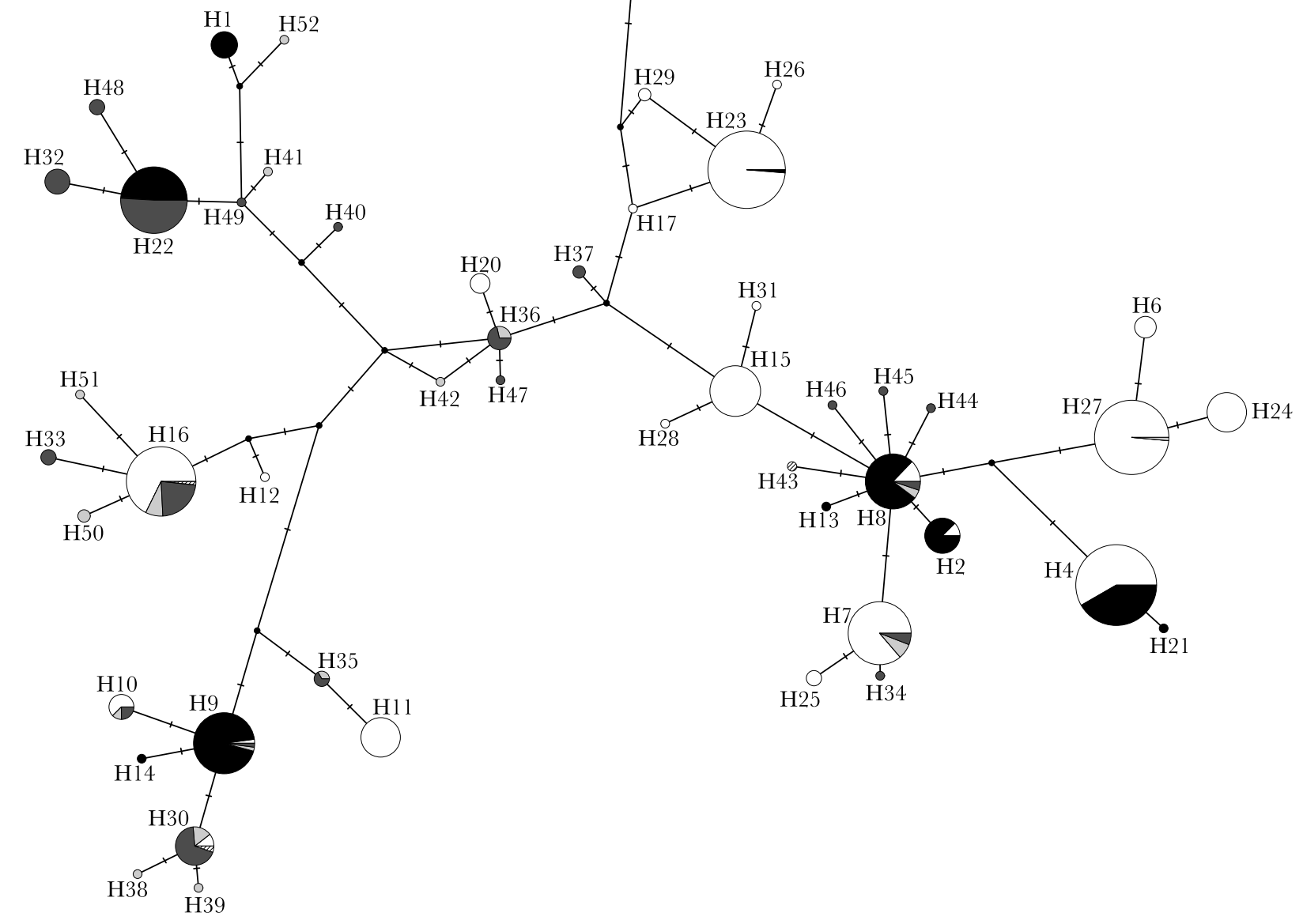

(b)

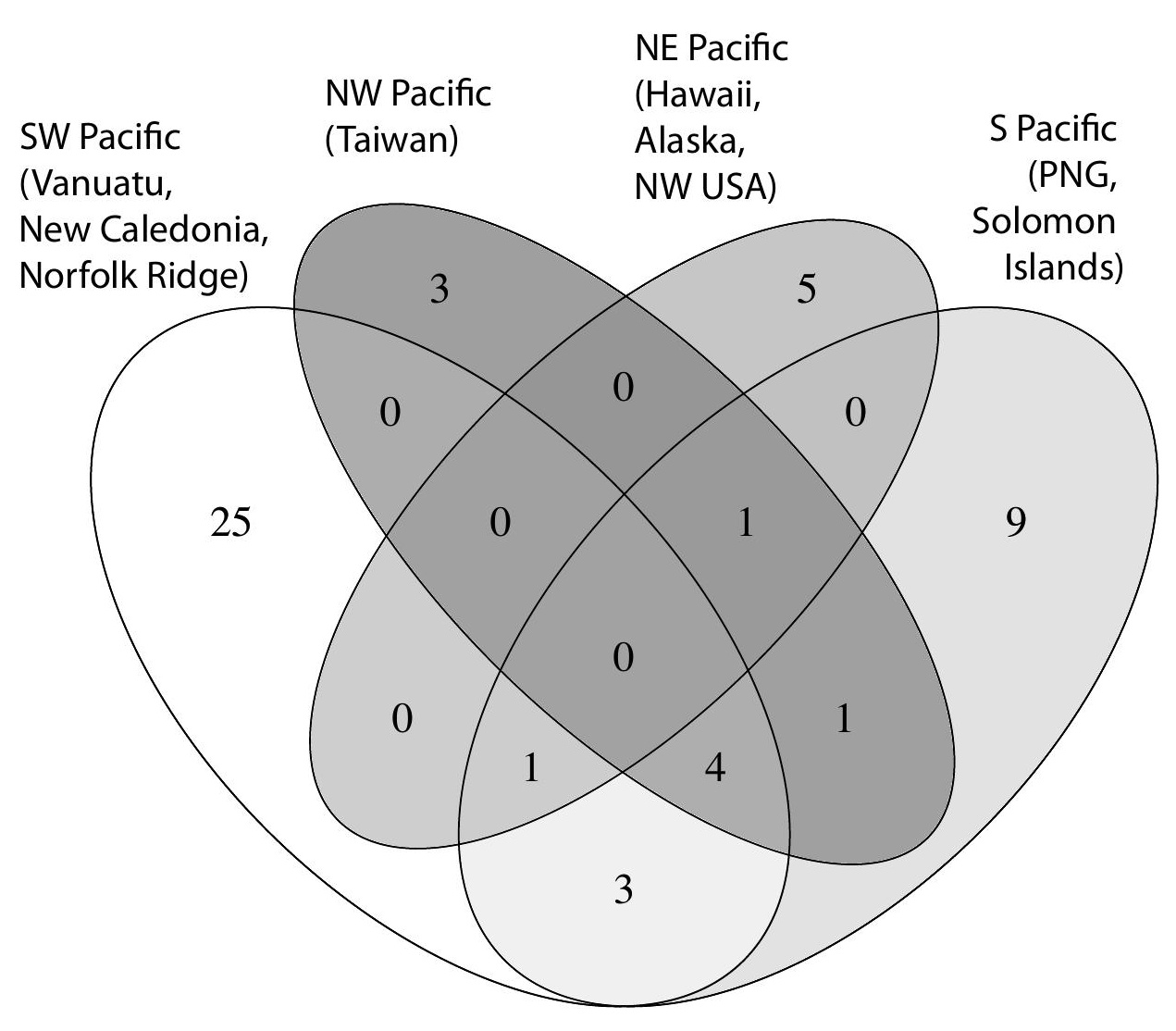




\title{
Journal of Biogeography
}

\section{SUPPORTING INFORMATION}

\section{An inter-ocean comparison of coral endemism on seamounts: the case of Chrysogorgia}

\author{
Eric Pante, Scott C. France, Delphine Gey, Corinne Cruaud, and Sarah Samadi
}

APPENDIX S2 Supplemental text.

\section{Study area: geology, oceanography, and associated fauna}

The south-west Pacific Norfolk Ridge (NR) is approximately $1500 \mathrm{~km}$ long and $200 \mathrm{~km}$ wide, and connects the south-eastern tip of New Caledonia to the north-western tip of New Zealand. The seamounts along this ridge have, on average, summit depths between 700 and $1000 \mathrm{~m}$ towards the north-east, and between 250 and $500 \mathrm{~m}$ towards the south-west. Some seamount summits are particularly shallow, such as Antigonia Seamount, which peaks at $57 \mathrm{~m}$ depth (Allain et al., 2008). The Loyalty Ridge (LR) runs parallel to the NR, and harbours many deep seamounts (summit depths 750-1000 m). The NR and LR are separated by a sedimentary basin that is $2500 \mathrm{~m}$ deep and $70 \mathrm{~km}$ wide (Dupont et al., 1995). A total of 57 underwater features were catalogued from the New Caledonian exclusive economic zone (Allain et al., 2008), including 17 seamounts more than $1 \mathrm{~km}$ tall. Most seamounts are shorter, and can be considered guyots (Castelin, 2010).

Sub-surface currents around New Caledonia are mainly influenced by the South Equatorial Current (SEC), which flows westward and passes between New Caledonia and the Solomon Islands (Kessler \& Cravatte, 2013, and references therein). The SEC is composed of several narrow currents, or jets, two of which pass by New Caledonia (the

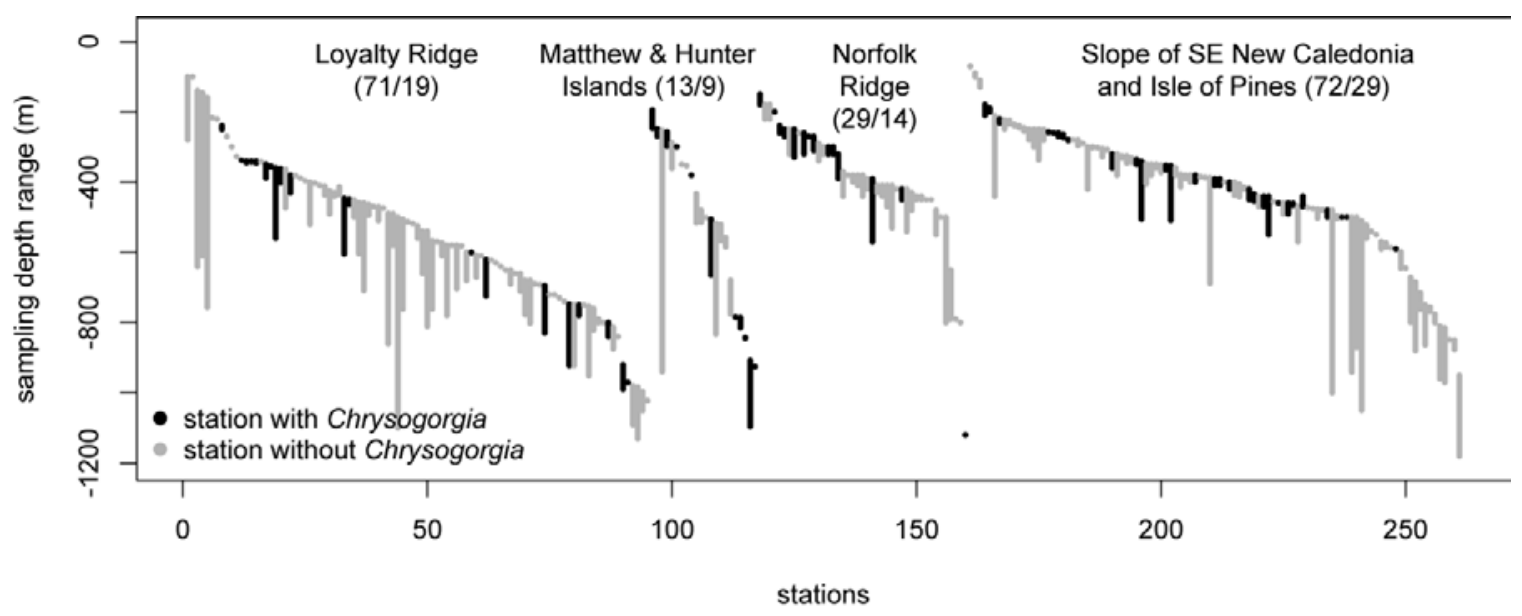

Figure S1 Bathymetric range of sampling stations for the Terrasses and ExBoDi cruises. Vertical segments connect the shallower and deeper sampling depths for each station. Shade represents the presence (black) or absence (grey) of Chrysogorgia at each station. The numbers of stations with/without Chrysogorgiaare provided in parentheses for each group. 
westward Northern Caledonian Jet, NCJ, and Southern Caledonian Jet, SCJ). These jets split from the South Fiji Jet at the southern tip of Vanuatu. The NCJ first flows northwest along the Loyalty Ridge, and continues west as it passes the northern tip of New Caledonia. The SCJ leaves the southern tip of Vanuatu to go over the Norfolk Ridge and, further west, over the Lord Howe Rise (see Fig. 6 in Kessler \& Cravatte, 2013).

The taxonomy of Chrysogorgia in this zone is very poorly known. Whereas 25 species are known from the Malay Archipelago, only one species was documented from New Caledonia (Bayer \& Stefani, 1988), and there are no records of Chrysogorgia specimens identified to the species level within a $1300-\mathrm{km}$ radius of this location. We are in the process of testing species hypotheses using genomic markers (Pante et al., 2014) and plan to formally describe Chrysogorgia species from the SW Pacific area. In the following sections, we will refer to the south-western slope of New Caledonia as 'the slope'.

\section{Correspondence between haplotypes and nominal species}

A single nominal species of Chrysogorgia (C. admete, Bayer \& Stefani, 1988) is currently known from the area (type locality: south-eastern slope of New Caledonia). We attempted, without success, to amplify mtMutS from the holotype of this species. Preliminary observations suggest that colony morphology correlates well with genetic identity within the region, and that $m t M u t S$ haplotypes might therefore represent evolutionary units that are close to the species level. Specimens belonging to haplotype 12 are among the rare pinnate colonies ever collected. It is, however, genetically distinct from the only pinnate Chrysogorgia species described to date (C. pinnata Cairns, 2007), suggesting that this specimen belongs to an undescribed species.

\section{Evaluation of putative endemism, haplotype richness and sampling biases}

\section{Computer simulation methods}

To test whether unrecognized species diversity significantly affects our estimates of connectivity between island slopes and seamounts, we performed computer simulations in which haplotypes were split into two species of equivalent biogeography. For example, if a haplotype present both on slopes and on seamounts represents two species instead of one, these two species may both be present on seamounts and slopes. Alternatively, one of them may be present in both environments, whereas the second is (1) absent from both environments, (2) present on slopes but not seamounts, or (3) present on seamounts but not slopes. We used the presence-absence matrix built for slopes and Norfolk Ridge stations (16 haplotypes in common) to perform simulations in R. We split 1-16 haplotypes (sampled at random without replacement) into two species each. The presence/absence pattern of the two 'new' species are chosen at random, but always match the original haplotype biogeography. The modified matrices therefore contained 17-32 species. Jaccard's dissimilarity index (JI) was recalculated for the modified matrix, and 1000 replicates were performed for each condition (total of $16 \times 1000$ simulations). 


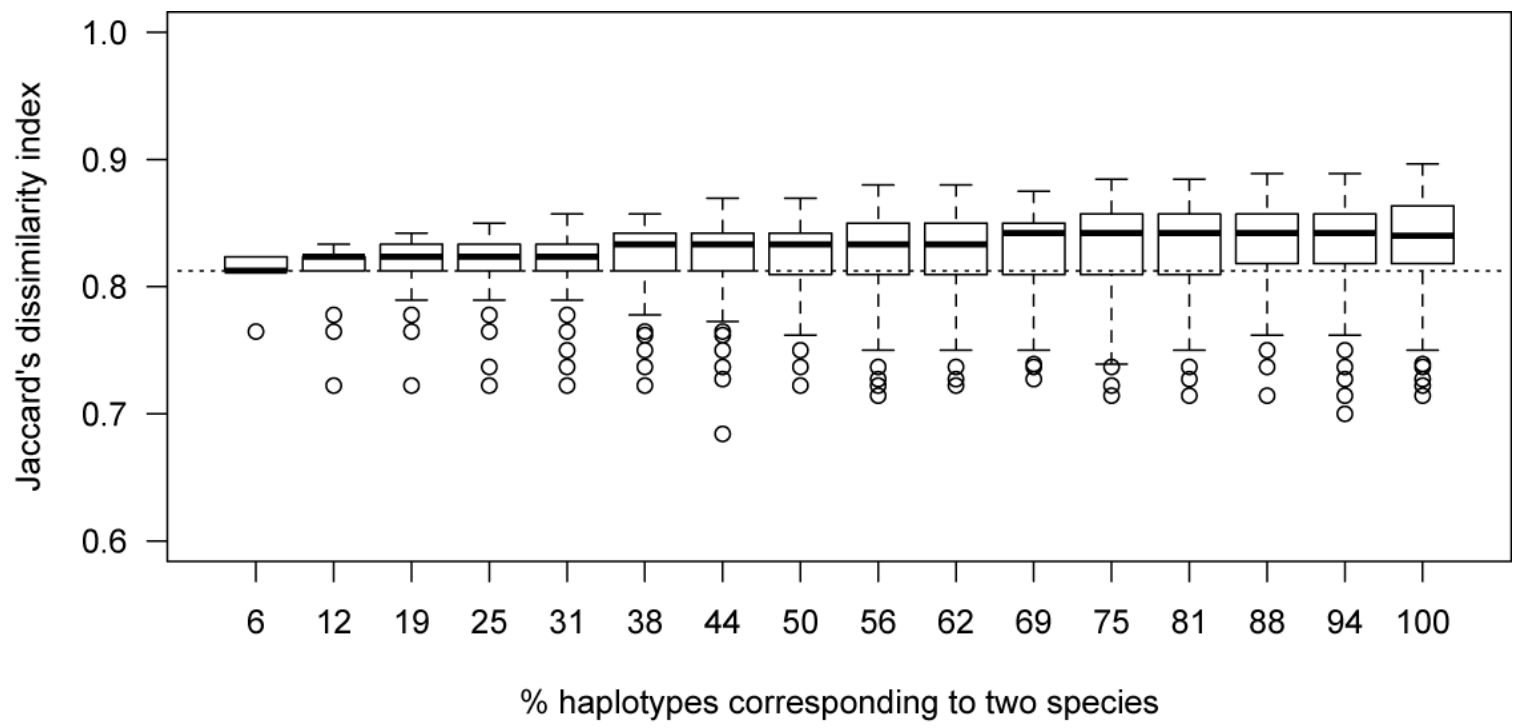

Figure S2 Results of the species simulation study comparing the slope of New Caledonia and the seamounts from the northern end of the Norfolk Ridge. Distributions (represented as box-and-whisker plots) of Jaccard's dissimilarity index (JI) when haplotypes (from 1 to 16) are split into two species of equivalent biogeography. The horizontal dashed line represents the observed value of JI for 16 haplotypes. The thick black line represents the median of simulated data. Boxes include data from the first to the third quartile, and vertical bars represent the non-outlier range. Outliers are defined as values $>1.5$ the interquartile range.

\section{Results of computer simulations}

Computer simulations aiming at artificially splitting haplotypes into two putative species show an increase in median JI with increasing number of species (i.e. slopes and seamounts become more dissimilar as the number of species increases), and an increase in the variance of JI with increasing number of species (see Fig. S2). These increases are, however, moderate: when all haplotypes are split into two species (total of 32 species), $\mathrm{JI}$ varies between 0.73 and 0.89 , with a median of 0.84 . The observed JI of 0.81 , calculated on the empirical data based on 16 haplotypes, is included in the simulated interquartile range of most simulation sets $(11 / 16$ sets; overall interquartile range for all 16,000 simulations: 0.81-0.84).

\section{ACKNOWLEDGEMENTS}

We are grateful to the crew of the R/V Alis, the organizers and participants of the TDSB cruises, MNHN collections personnel, members of the Service de Systématique Moléculaire at the MNHN, members of the France Lab at the University of Lafayette, Les Watling and Steven Cairns for their insights on octocoral systematics. The BIOPAPUA, EXBODI, MADEEP, Norfolk 2, Salomon 1, Salomon 2, SMIB 4, TERRASSES cruises were organized with required permits onboard of the R/V Alis, financed by Institut de Recherche pour le Développement (IRD). The TAIWAN2013 cruise was organized by Wei-Jen Chen (National Taiwan University) and Tin-Yam Chan (National Taiwan Ocean University) on board Ocean Research $1 \& 3$. The PAPUA NIUGINI specimens were obtained during the 
'Our Planet Reviewed' Papua Niugini Biodiversity Expedition organized by MNHN, Pro Natura International (PNI), IRD and University of Papua New Guinea (UPNG), under principal investigators Philippe Bouchet, Claude Payri and Sarah Samadi. The organizers acknowledge funding from the Total Foundation, Prince Albert II of Monaco Foundation, Fondation EDF, Stavros Niarchos Foundation and Entrepose Contracting, and in-kind support from the Divine Word University (DWU). The expedition operated under a permit issued by the Papua New Guinea Department of Environment and Conservation. We thank the PIs and crew members of the various other expeditions that allowed our biogeographical comparisons. Specimens from New Zealand were provided by the NIWA Invertebrate Collection (RENEWZ I - NEW ZEEPS voyage, the first component of the project Exploration of Chemosynthetic Habitats of the New Zealand Region, funded by NOAA-OE and NIWA, with cofunding from Woods Hole Oceanographic Institution, Scripps Institution of Oceanography and the University of Hawaii), and were collected during the Voyages TAN0308 ['Norfolk Ridge / Lord Howe Rise Marine Biodiversity Discovery Survey (NORFANZ)', PI Malcom Clark, NIWA], jointly funded by the Australian National Oceans Office and the New Zealand Ministry of Fisheries, TAN0413 ('Bay of Plenty \& Hikurangi Plateau Seamounts: their importance to fisheries and marine ecosystems', PI Malcolm Clark, NIWA), and KAH0011 ('Bay of Plenty and southern Kermadec Arc Seamounts Biodiversity survey', PI Malcolm Clark, NIWA), undertaken by the NIWA and funded by the New Zealand Foundation for Research, Science and Technology with additional funding from the Ministry of Fisheries. Support for this research was provided by funding of the French National Agency for Research (ANR) under the grant Bioneocal (PI Philippe Grancolas ANR-07-BDIV-0006) and the FrenchTaiwanese grant TF-DeepEvo (co-PIs Sarah Samadi and Wei-Jen Chen) co-funded by the ANR (ANR 12-ISV7-0005-01) and the Ministry of Science and Technology, Taiwan, R.O.C.; to E.P. from Sigma Xi (GIAR G20061021830514629), the American Museum of Natural History (Lerner Gray Fund), the University of Louisiana at Lafayette Graduate Student Organization, and Paulyn Cartwright (University of Kansas). This work was supported by the 'Consortium National de Recherche en Génomique', and the 'Service de Systématique Moléculaire' of the MNHN (CNRS UMS 2700) and the project 'Taxonomie moléculaire: DNA Barcode et gestion durable des collections' funded by the MNHN. It is part of the agreement no. 2005/67 between the Genoscope and the MNHN on the project 'Macrophylogeny of life' directed by Guillaume Lecointre.

\section{REFERENCES}

Allain, V., Kerandel, J.A., Andrefouet, S., Magron, F., Clark, M., Kirby, D.S. \& Muller-Karger, F.E. (2008) Enhanced seamount location database for the western and central Pacific Ocean: screening and crosschecking of 20 existing datasets. Deep-Sea Research Part I, 55, 1035-1047.

Bayer, F. \& Stefani, J. (1988) A new species of Chrysogorgia (Octocorallia: Gorgonacea) from New Caledonia, with descriptions of some other species from the Western Pacific. Proceedings of the Biological Society of Washington, 101, 257-279.

Cairns, S.D. (2007) Calcaxonian octocorals (Cnidaria; Anthozoa) from Eastern Pacific Seamounts. Proceedings of the California Academy of Sciences, 58, 511-541.

Castelin, M. (2010) Lien entre endémisme et développement larvaire en milieu marin. Le cas des gastéro- 
podes des monts sous-marins de la Zone Economique Exclusive de Nouvelle Calédonie. PhD dissertation, Muséum national d'Histoire naturelle.

Dupont, J., Lafoy, Y., Pautot, G., Le Suavé, R., Cluzel, D., Missegue, F., Grandperrin, R., Henin, C., Voisset, M., Stomer, L., Gautheron, L., Butscher, J., Mollard, L. \& Rakoia, M. (1995) Morphostructural study of the southern zone of New Caledonia and Loyalty Ridges (EEZ of New Caledonia, SW Pacific). Comptes Rendus de l'Académie des Sciences Série II, 320, 211-218.

Kessler, W.S. \& Cravatte, S. (2013) Mean circulation of the Coral Sea. Journal of Geophysical Research: Oceans, 118, 1-26.

Pante, E., Abdelkrim, J., Viricel, A., Gey, D., France, S.C., Boisselier, M.-C. \& Samadi, S. (2014) Use of RAD sequencing for delimiting species. Heredity, advance online publication; doi:10.1038/hdy.2014.105 
Appendix S3: Median-joining network for Pacific Chrysogorgia haplotypes, plotted by depth (top) and geography (bottom).
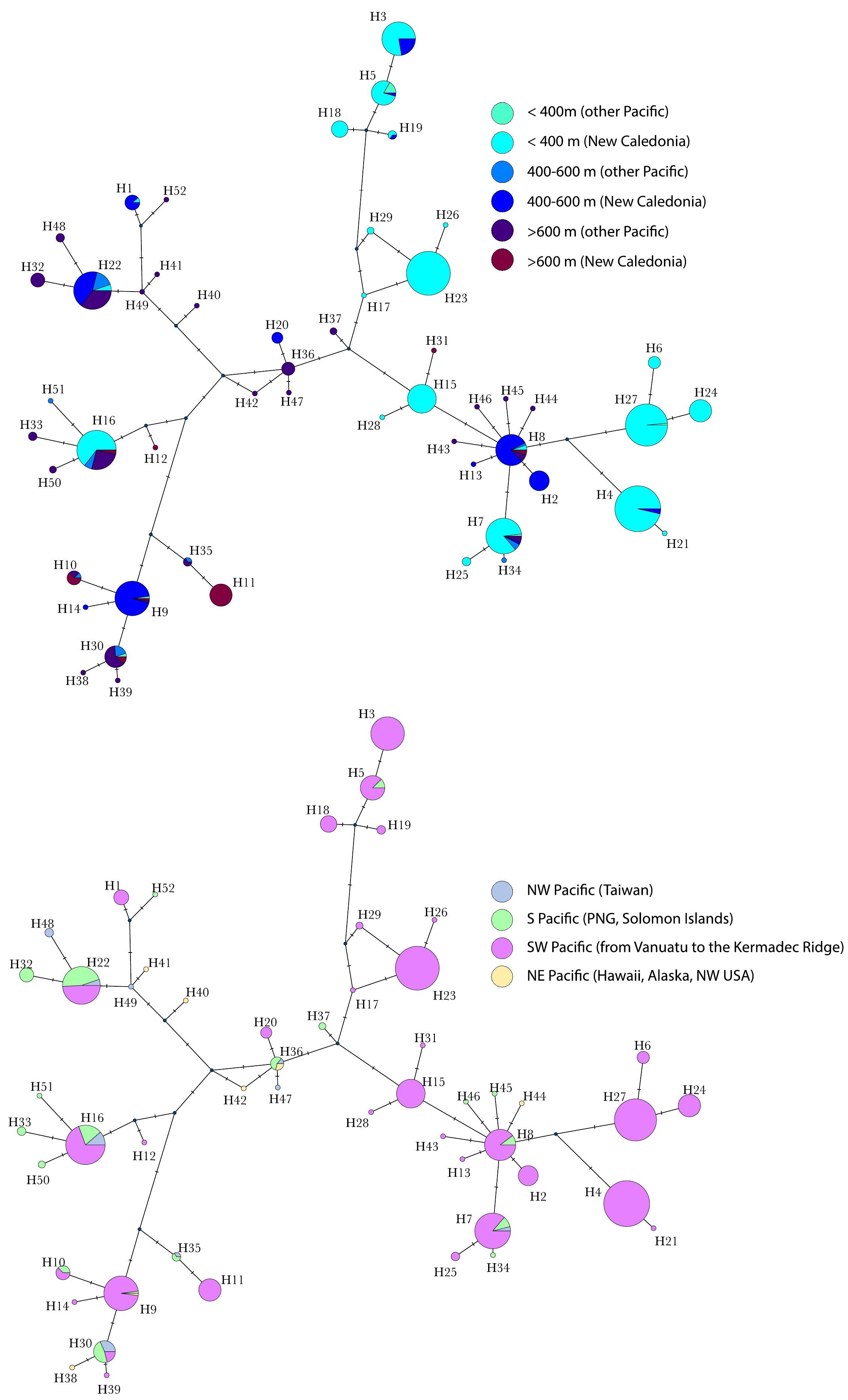